\title{
Quantification of 4-nerolidylcatechol from Pothomorphe umbellata (Piperaceae) in rat plasma samples by HPLC-UV
}

\author{
Kênnia Rocha Rezende*, Sílvia Berlanga de Moraes Barros \\ Departamento de Análises Clínicas e Toxicológicas, Faculdade de Ciências Farmacêuticas, \\ Universidade de São Paulo
}

*Correspondence:

K. R. Rezende

Núcleo de Estudos e Pesquisas Tóxico-

Farmacológicas - (NEPET)

Faculdade de Farmácia

Universidade Federal de Goiás

Pça Universitária com $1^{\text {a }}$. avenida $\mathrm{S} / \mathrm{N}$

Setor Universitário

74605-220 - Goiânia - GO, Brasil.

E-mail: kennia@farmacia.ufg.br

\begin{abstract}
The oral dosages formulations from Pothomorphe umbellata (Piperaceae) can only be therapeutically evaluated after establishing 4-nerolidylcatechol (4-NRC) pharmacokinetic profile in plasma. For that purpose, a unique analytical method validation using HPLC-UV detection was developed for analysis of rat plasma samples. The animals received $10 \mathrm{mg} / \mathrm{kg} \mathrm{b.w.} \mathrm{of} \mathrm{4-NRC} \mathrm{i.v..}$ Analytical conditions were set with C18 column, methanol: acetonitrile: water (62:20:18) as mobile phase, and a flow rate of $1.6 \mathrm{~mL} / \mathrm{min}$. The assay was linear from $1.0-80.0 \mathrm{mcg} / \mathrm{mL}$. The recovery procedure was performed by liquid-liquid extraction showing quantitative extraction (106.4 $8.7 \%)$. Limit of Quantification (LOQ) was found to be $1.0 \mathrm{mcg} / \mathrm{mL}$. Interassay precision and accuracy ranged from values of 14.4-3.0\% and 24.0$0.2 \%$, respectively. Recovery after liquid-liquid extraction was found to be $106.5 \pm 3 \%$. The method is simple and reliable with total run time of less than $15 \mathrm{~min}$.
\end{abstract}

Uniterms:

- 4-Nerolidylcatechol

- Pothomorphe umbellata

- HPLC-UV

- Liquid-liquid extraction

\section{INTRODUCTION}

In recent years, there has been a growing interest in the compound 4-nerolidylcatechol found in some Piperaceae shrubs. 4-Nerolidylcatechol (4-NRC) is the major secondary metabolite from Pothomorphe peltata and Pothomorphe umbellata traditionally used for treatment of hepatic disorders on Brazilian Southwest and Amazon area, respectively (Silva, 1926; Di Stasi et al., 1994). Pharmacological studies involving quenching of lipid peroxidation have shown remarkable antioxidant activity for 4-NRC when compared with a-tocopherol (Barros et al., 1996; Desmarchelier et al., 1997). Corroborating these studies, 4 -NRC $0.1 \%(\mathrm{w} / \mathrm{w})$ was added to topic skin formulations showing UV protection and percutaneous absorption (Röpke et al., 2002). Additionally, crude ethanolic extracts of $P$. umbellata leaves have demonstrated antimalarial activity (Amorim et al., 1988) and absence of mutagenic effects in Salmonella typhimurium (Felzenszwalb et al., 1987) and on micronuclear erythrocytes (Barros et al., 2001). Furthermore, dimmers of 4-NRC have also shown antiHIV activity (Gustafson et al., 1992).

However, for preclinical studies it is essential to establish pharmacokinetic properties (De Smet, Rouwers, 1997; Hamburguer, Hostettmann, 1991) and assess pharmacological levels associated with the safety and efficacy of the drug. Therefore, a sensitive and reliable 
analytical method must be developed to assess such properties for the compound of interest.

The chemical structure of 4-nerolidylcatechol (1) was first described in a hexane extract (Kijoa et al., 1980), which also contained various phenylpropanoids such as apiol (Silva, Baver, 1972), dilapiol (Bernard, Tieli, 1978) and the sesquiterpene nerolidol. Since then, several other substances were identified in more polar extracts. These include some flavonoids, lignans (Bastos, 1998) and dimmers (peltatols A, B and C) of the prenylated catechol (Gustafson et al., 1992).

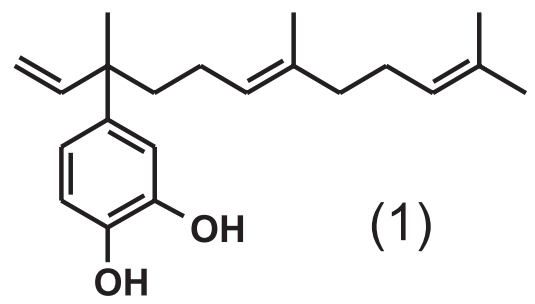

Several analytical methods for phenols, catechols and polyphenols molecules are available. However, physicochemical properties of catechol-containing molecules show predominant water solubility (i.e. polyphenols) instead of liposolubility $(\log \mathrm{P}=6.03)$, as depicted for 4-NRC (Freitas, 1999). Therefore, in response to the need for a sensitive method to quantify 4-NRC, we examined methods using liquid chromatography coupled to electrochemical detection (Cai et al., 1999; Stremetzne, Jaehde, Schumack, 1997; Holmes, Eisenhofer, Goldstein, 1994; Lunte, 1987; El-Shafae, El-Domiaty, 2001) and ultraviolet detection (Romanova et al., 2000; Rouseff et al., 1992; Ruperez et al., 1999; Castagnetta et al., 1992), as primarily options. Such methods generally show suitable sensitivity for plasma samples, even when compared to more selective ones (Lee et al., 1993; Stecher et al., 2001). In addition, those equipments are easily handled and available in most laboratories.

Thus, the aim of this work was to develop an HPLCUV method for preliminary quantification and assessment of biological interferences of 4-nerolidylcatechol in rat plasma after $i v$ dosing.

\section{MATERIAL AND METHODS}

\section{Materials and reagents}

HPLC grade acetonitrile, methanol and hexane were purchased from Fisher Scientific (Pittsburgh, PA, USA), filtered under vacuum through $0.45 \mathrm{~mm}$ Teflon filter (Millipore, Bedford, MA, USA) and degassed under ultrassonication (15 min/L). 2, [6]-Di-tert-butyl-p-cresol
(BHT) was purchased from Sigma (St. Louis, MO, USA). Male Wistar rats (275-325g) were purchased from Faculdade de Medicina Veterinária e Zootecnia - Universidade de São Paulo. Preparative column chromatography under vacuum and preparative radial thin-layer chromatography (Chromatotron ${ }^{\mathrm{TM}}$ model 8924) experiments used Silica gel 60 H (Merck, 63 - $210 \mathrm{~mm}$ ) and Silica gel PF with binder (Merck, Cat.7749) as adsorbents, respectively.

\section{Methods}

\section{Chromatographic conditions}

A reverse phase column Zorbax SB C18, 4.6 X 150 $\mathrm{mm}, 5-\mathrm{mm}$ (Chromatography Specialties, Mississauga, ON, Canada) with an HPLC Constametric 3200 system was coupled to UV detector (1049A WATERS) at $282 \mathrm{~nm}$. Auto-sampler interface was accomplished by HP 3396 series III with a Reodyne injector loop $(20 \mathrm{~mL})$. Aliquots were injected and eluted with methanol-acetonitrile-water $(62: 20: 18, \mathrm{v} / \mathrm{v} / \mathrm{v})$ as isocratic mobile phase mixture. Flow rate was set at $1.6 \mathrm{~mL} / \mathrm{min}$.

\section{Purification of 4-nerolydilcatechol and its extraction from plasma}

Leaves of Pothomorphe umbellata were collected in February 1998 at Piperaceae's garden of Instituto de Química, Universidade de São Paulo. A voucher specimen (Kato-0363) was identified by Dra. Inês Cordeiro (Universidade Federal do Paraná - Curitiba) and deposited in the herbarium of Instituto de Botânica (Secretaria do Meio Ambiente do Estado de São Paulo).

Leaves (1 kg) were dried, milled and exhaustively extracted with $\mathrm{MeOH}$ yielding $184.2 \mathrm{~g}$ of crude extract after solvent evaporation. The leaves extract (180.0 g) was resuspended in $\mathrm{MeOH}: \mathrm{H}_{2} \mathrm{O}(8: 2)$ and filtered through a celite column $(10 \times 10 \mathrm{~cm})$ to remove pigments and lipophilic interferents from the matrix. Solvent evaporation yielded a solid residue (84.1 g). Next, a small aliquot (10 g) was applied to a flash-filtering column on silica gel $60 \mathrm{H}$ $(10 \times 10 \mathrm{~cm})$ using $\mathrm{CHCl}_{3}$ as eluent. The $\mathrm{CHCl}_{3}$ extract residue $(6.1 \mathrm{~g})$ was solubilized in hexane $(20 \mathrm{~mL})$, fractionated (6x) and submitted to preparative radial thinlayer chromatography (PR-TLC, $110.0 \times 4.0 \mathrm{~mm}$ ). Chromatographic conditions were flow rate of $8.0 \mathrm{~mL} / \mathrm{min}$ and eluotropic gradient of hexane: $\mathrm{CH}_{2} \mathrm{Cl}_{2}$ : methanol (10:5:1 up to $0: 5: 1)$ during $94 \mathrm{~min}$. Separation of constituents was monitored with a UV lamp at $254 \mathrm{~nm}$. Sample fractions were compared with authentic standard sample and submitted to final purification at PR-TLC (hexane:ethylacetate $80: 20 ; 8.0 \mathrm{~mL} / \mathrm{min}$ ). Evaporation of 
the residue yielded a pale yellow oil (1.2 g) chemically identified by ${ }^{1} \mathrm{H}$ and ${ }^{13} \mathrm{C} \mathrm{NMR}$, as 4-NRC. Its purity was not lower than $96 \%$ in analytical chromatographic conditions described herein.

\section{Root extract standardization}

Pothomorphe umbellata roots were cleaned, dried, milled $(822.5 \mathrm{~g})$ and percolated in $60 \%$ ethanol $(18 \mathrm{~L})$ as directed by Method A of Pharmacopeia dos Estados Unidos do Brasil (Silva, 1959). The pharmacopoeical preparation was submitted to solvent evaporation yielding a dried crude extract (78.5 g/9.5\%). Standardization was carried out using five accurate weighted $(0.5 \mathrm{mg} / \mathrm{mL})$ crude extract replicates. Quantification was measured against pure 4-NRC standard solutions in methanol. Results showed $21.5 \pm 3.3 \%$ of 4 -NRC contents.

\section{4-Nerolidylcatechol solutions and calibration standards}

4-NRC stock solution was prepared in methanol to achieve $100.0 \mu \mathrm{g} / \mathrm{mL}$, as a final concentration. Next, work solutions were prepared to give five standard points in mobile phase that were stored at $-70{ }^{\circ} \mathrm{C}$. All five work stock solutions were set in a manner such that the same aliquot amount was taken and spiked in plasma matrix (e.g. $100 \mu \mathrm{L}$ work solution/1 mL plasma). Subsequently, calibration standards were prepared in pooled plasma samples spiked with known amounts of the work solutions to give final concentrations of $1.0 ; 3.0 ; 20.0 ; 50.0$; $80.00 \mu \mathrm{g} / \mathrm{mL}$. Aliquots of $250 \mu \mathrm{L}$ spiked plasma samples were transferred to borosilicate tubes using micropipettes (Gilson, USA), capped with PE plugs (Fischer Scientific, USA) and kept at $-17^{\circ} \mathrm{C}$. Thaw of samples were carry out when necessary to run daily calibration curves.

\section{Plasma sample preparation}

The 4-NRC extraction procedure from plasma samples was prepared in media containing BHT $(8.0 \mathrm{mg} / \mathrm{L})$ as antioxidant agent. $1 \mathrm{~mL}$ of methanol/ethanol $(1: 1)$ was added to $250 \mu \mathrm{L}$ of plasma, followed by vortex mixing (1 minute). Next, water $(500 \mu \mathrm{L})$ and hexane $(2 \mathrm{~mL})$ were added. Subsequent to sealing the tubes, horizontal agitation was performed ( $3 \times 20 \mathrm{~min})$. Fresh hexane portions were added three times followed by centrifugation. The upper (hexane) layers were removed after "snap freezing" technique under liquid nitrogen and transferred to clean borosilicate tubes. After gathering it was evaporated under $\mathrm{N}_{2}$ stream. The residue was ressuspended in $250 \mu \mathrm{L}$ of methanol/water (85:15). Solutions were covered with aluminum foil and left at room temperature for $10 \mathrm{~min}$ and $20 \mu \mathrm{L}$ were injected in HPLC system.

\section{Validation results}

The method was validated for linearity, selectivity, recovery, accuracy, precision and stability in plasma samples. The analyte retention time in plasma and crude plant extract samples was found to be $6.3( \pm 0,23) \mathrm{min}$ and the total run time was set at $14.5 \mathrm{~min}$.

\section{- Assessment of Linearity and Selectivity}

Linearity over dynamic range ( 1.0 to $80.0 \mu \mathrm{g} / \mathrm{mL})$ was assessed by duplicate analysis of five points, during 3day period. 4-NRC quantification was measured by peak height response and derived from a standard curve performed in both plasma and methanol matrix (crude extract quantification). Results based on average correlation coefficient $-\mathrm{R}^{2}$ showed great linearity (0.994 \pm 0.002$)$.

Selectivity was determined by analyzing blank plasma samples from four different Wistar rats. Suitable 4NRC separation from plasma constituents was shown and no coincident interferences to analyte retention time were detected.

\section{- Recovery of 4-nerolidylcatechol}

Following plasma spiking, the amount of 4-NRC recovered was estimated at all five-point calibration standards and analyzed on three different days (Table I). Pooled plasma samples were prepared based on standard technique addition. Six estimations were made on each calibration standard. Recovery was calculated as the ratio

TABLE I - Summary for recovery of added 4-nerolidylcatechol

\begin{tabular}{cccc}
\hline 4-NRC added concentration in plasma & $\begin{array}{c}\text { Average concentration } \\
(\mathbf{m g} / \mathbf{m L} \mathbf{)}\end{array}$ & $\begin{array}{c}\text { Coefficient of } \\
\text { Variation } \mathbf{( \% )}\end{array}$ & $\begin{array}{c}\text { Recovery } \\
\mathbf{( \% )}\end{array}$ \\
\hline 1 & $1.06 \pm 0.134$ & 12.66 & 105.8 \\
3 & $3.57 \pm 0.228$ & 6.38 & 119.0 \\
20 & $18.31 \pm 1.723$ & 9.41 & 91.6 \\
50 & $53.94 \pm 3.373$ & 6.25 & 107.9 \\
80 & $85.86 \pm 8.210$ & 9.56 & 107.3 \\
\hline
\end{tabular}


between peak height response of extracted and not extracted analyte (standard work solutions added to extracted blank plasma) from each plasma sample. The value is expressed as the ratio between average experimental and nominal concentration of the analyte, multiplied by $100 \%$. The results summarized in Table I indicate quantitative average recovery of $106.4 \pm 8.7 \%$ in plasma.

\section{- Accuracy and precision}

Analytical method accuracy and precision were assessed by daily duplicate analysis of samples containing known amounts of 4-nerolidylcatechol ( 1.0 up to $80.0 \mu \mathrm{g} / \mathrm{mL}$ ), during 3-day period. These samples were prepared by the standard addition technique. Spiked plasma samples were stored at $-80^{\circ} \mathrm{C}$, fractionated as single aliquots $(250 \mu \mathrm{L})$ throughout the period of experiment.

The limit of detection (LOD) was determined using four pooled blank plasma sample spiked with work standard solutions. LOQ was set for the lowest concentration standard curve measured with acceptable accuracy and precision ( $\mathrm{SD} \pm 25.0 \%$ ). LOQ was inferred as three times the LOD, which was found to be $1.0 \mu \mathrm{g} / \mathrm{mL}$.

Interassay precision was determined by coefficient of variation $(\mathrm{CV})$ obtained by the ratio between standard deviation and average mean of replicates, during 3-day validation. Sample precision was found to be in the range of $14.4-3.0 \%$, as detailed on Table II. Intrassay precision was surely lower than interassay precision and not shown here.

Accuracy was assessed by the ratio between average relative error around the mean and added concentration, during 3-day validation experiments. The results are summarized in Table II. The accuracy relative error found for LOQ was $24 \%$ while it was between $19.7-0.2 \%$ for $3-80.0 \mu \mathrm{g} / \mathrm{mL}$ concentration range.

- Assessment of stability under freeze/thaw conditions

Storage conditions were evaluated by freeze-thaw stability comparing the 4-NRC amount found in samples that had been frozen $\left(-80{ }^{\circ} \mathrm{C}\right)$ and thawed $\left(20^{\circ} \mathrm{C}\right)$ three times with fresh plasma samples. Each freeze-thaw cycle duration was no less than $12 \mathrm{~h}$. The stability maintained for at least 4 weeks, based on chromatographic evidence indicating no apparent deterioration, which means not more than $2.9 \%$ difference on the amount of 4 -NRC. These

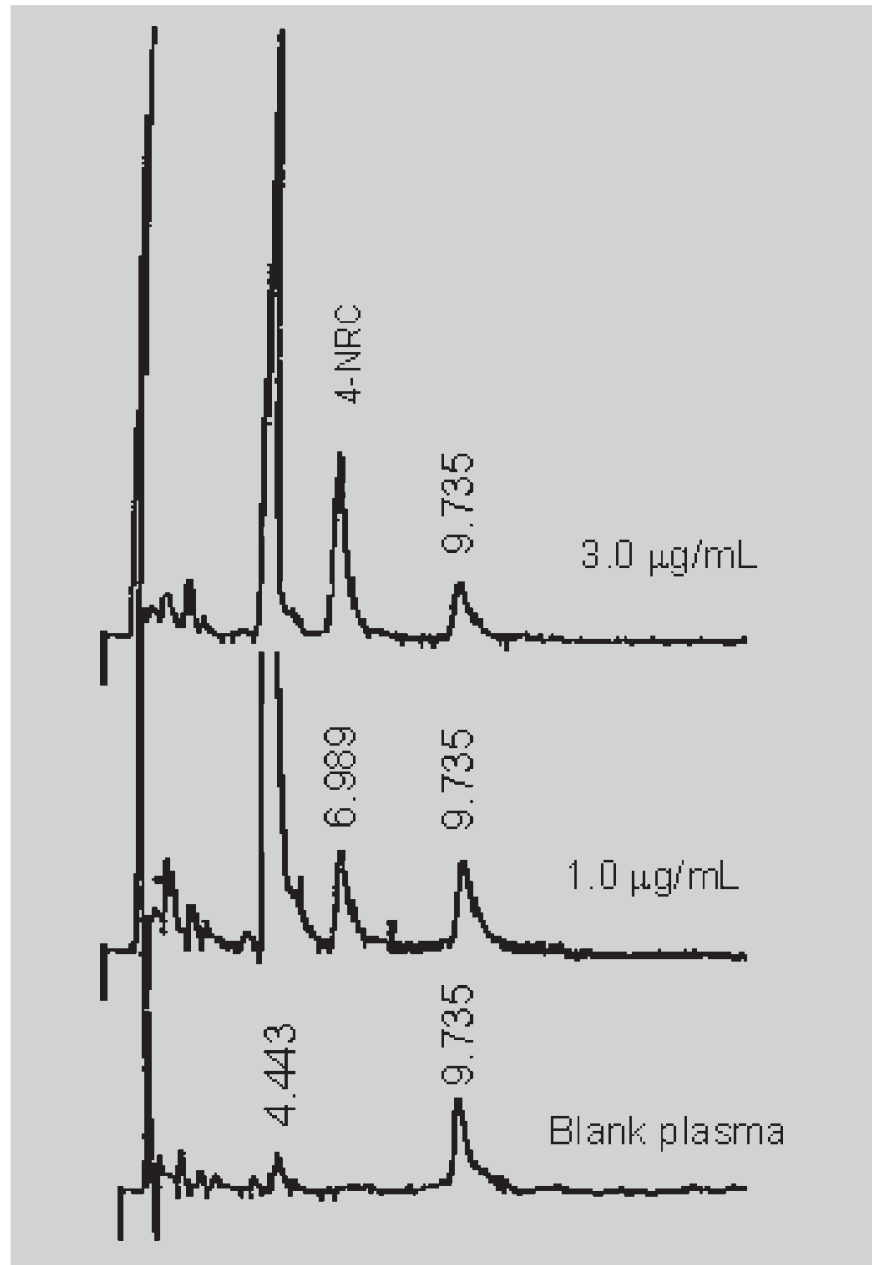

FIGURE 1 - Typical chromatogram of blank plasma (C) and spiked plasma with 4-nerolidylcatechol at $1,0 \mu \mathrm{g} / \mathrm{mL}$ de 4-NRC (B) and 3,0 $\mu \mathrm{g} / \mathrm{mL}$ de 4-NRC (A).

TABLE II - Summary of interassay precision and accuracy of calibration curves during 3-day

\begin{tabular}{|c|c|c|c|c|c|c|c|c|}
\hline & \multirow[t]{2}{*}{$\mathbf{R}^{2}$} & \multirow[t]{2}{*}{ slope } & \multirow[t]{2}{*}{ intercept } & \multicolumn{5}{|c|}{ 4-NRC spiked plasma concentrations $(\mu \mathrm{g} / \mathrm{mL})$} \\
\hline & & & & 1. 0 & 3.0 & 20. 0 & 50.0 & 80.0 \\
\hline Mean $(\mathbf{n}=9)$ & 0.994 & 4213.47 & 1628.58 & 1.24 & 3.59 & 17.89 & 50.87 & 80.13 \\
\hline & 0.002 & 368.56 & 1676.94 & 17.80 & 0.35 & 1.86 & 3.24 & 2.39 \\
\hline Precision* & $0.22 \%$ & $8.75 \%$ & 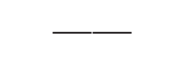 & $14.36 \%$ & $9.75 \%$ & $10.38 \%$ & $6.37 \%$ & $2.98 \%$ \\
\hline Accuracy** & -- & - & - & $24.0 \%$ & $19.67 \%$ & $10.55 \%$ & $1.74 \%$ & $0.16 \%$ \\
\hline
\end{tabular}

* CV (\%)- standard deviation/mean x 100\%; ** Error \%-(found concentration - nominal concentration)/nominal concentration $\times 100 \%$ 
results indicate 4-NRC is stable in rat plasma after three freeze-thaw cycles.

\section{Pharmacokinetic data applications}

4-NRC parenteral solution $(2.5 \mathrm{mg} / \mathrm{mL})$ was prepared in 30\% hydroxypropyl- $\beta$-cyclodextrin (Sigma, $\mathrm{St}$ Louis, USA) and filtered (Millipore, $0.45 \mu \mathrm{m}$ ). The drug was administered as i.v. bolus $(10 \mathrm{mg} / \mathrm{kg})$ through dissected femoral vein ( $27 \mathrm{G}$ needle), while animal body conditions (temperature and plasma volume) were maintained under control (warming paddle and 5 U.I. heparin solution reposition). Blood samples were collected after distal and proximal isolation of carotid artery portion (thread silk, 5.O.1), following its canulation with a catheter (FEP tubing, $22 \mathrm{G}$ ). Sample collection (eight time points; $300 \mu \mathrm{L}$ ) was set at the following schedule time: $0.0 ; 2.5$; $5.0 ; 7.5 ; 10.0 ; 15.0 ; 17.5 ; 20.0 ; 30.0 ; 45.0 ; 60.0 ; 70.0 \mathrm{~min}$ on heparinized eppendorf tubes. Blood samples were centrifuged (3000 rpm/2 min) and plasma was stored $\left(-80{ }^{\circ} \mathrm{C}\right)$ until analysis. The 4-NRC plasma concentration obtained at each time point is presented in Figure 2.

\section{DISCUSSION AND CONCLUSION}

A simple HPLC-UV method for analysis of 4nerolydilcatechol in plasma was developed. This method is based on liquid-liquid extraction and an isocratic reversedphase HPLC analysis with a total run time of less than 15 min, a run time frequently targeted with ultraviolet detection.
The accuracy maximum relative error for LOQ was set at $\pm 25 \%$. It can be partially justified by the absence of a suitable internal standard and also, by the 4-NRC high affinity to blood cells. This later assertion is based on additional evaluation of some bench-top conditions. Preliminary studies reinforce suspicions of high erythrocyte partition coefficient based on a high liposolubility of 4-NRC (Freitas, 1999). The assay procedure was based on literature (Boulton, Walle, Walle, 1999). Blood samples were spiked with 4-NRC $(50 \mathrm{mg} / \mathrm{mL})$ and quantified on triplicate. Analytical conditions were simulated keeping blood samples at controlled temperature $\left(0{ }^{\circ} \mathrm{C}\right.$ and $\left.37{ }^{\circ} \mathrm{C}\right)$ and incubation time ( 0.0 and $60.0 \mathrm{~min})$. Photoxidation during bench-top and in-process assays, including auto-sampler injection were prevented by aluminum foil protection. Results showed that blood aliquots, which were maintained at $37^{\circ} \mathrm{C} / 1 \mathrm{~h}$, yielded lower 4-NRC average recovery (66.9\%) in plasma when compared to samples immediately extracted or when kept under refrigeration $\left(0^{\circ} \mathrm{C} / 1 \mathrm{~h}\right)$. Similar findings are frequently seen on other lipophilic drug profiles (Derendorf et al., 1984; Derendorf, Garret, 1983). Several methodological conditions as sample concentration, $\mathrm{pH}$, temperature and protein binding (Boulton, Walle, Walle, 1999) are also important variables, but not yet controlled here. Therefore, further developments on this issue are to be carried out.

As a final point, the analytical method presented herein can be applied as an important approach to standardization of Pothomorphe umbellata roots extracts, previously to the determination of 4-NRC plasma level during pre-clinical phase trials. Additionally, this method

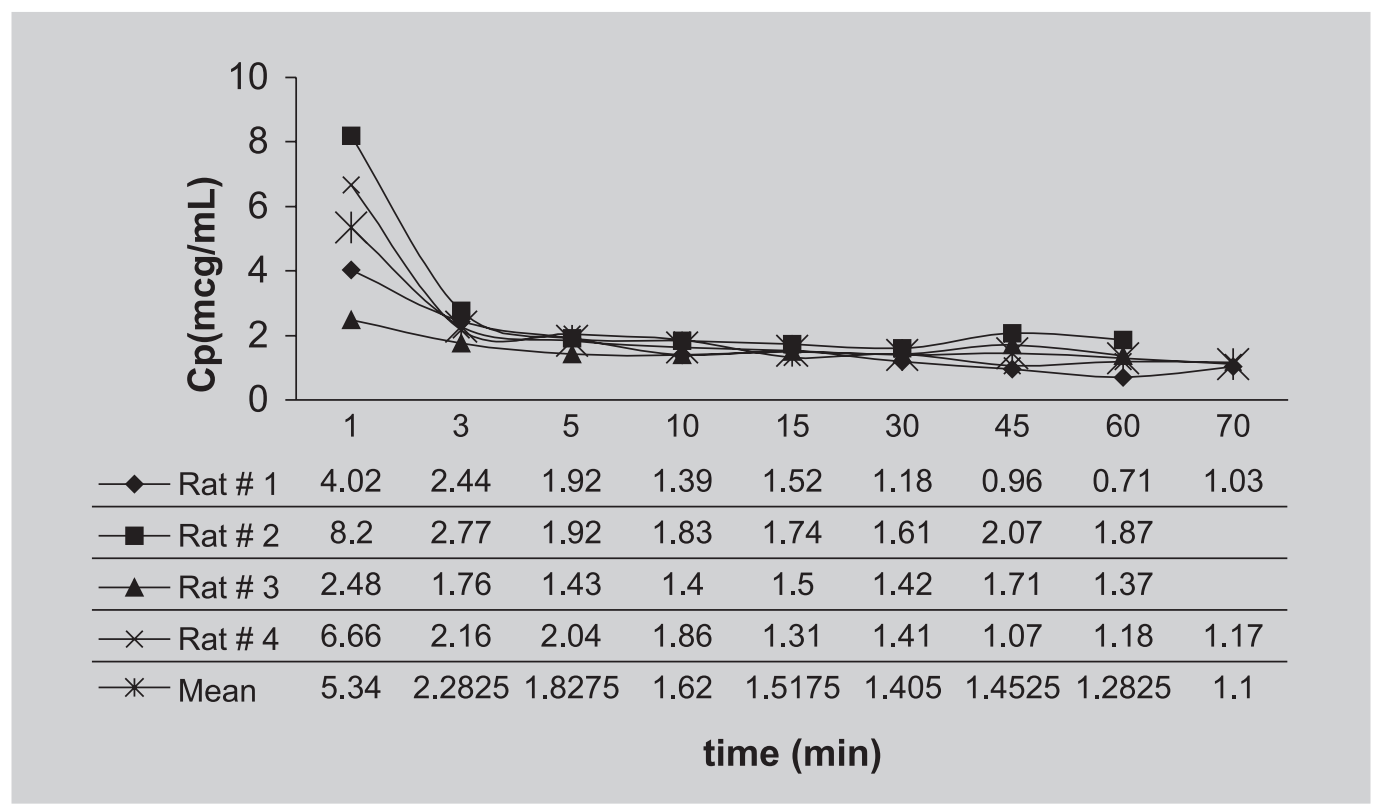

FIGURE 2 - Plasma concentration level of 4-NRC following iv bolus dosing of $10 \mathrm{mg} / \mathrm{kg}(2.5 \mathrm{mg} / \mathrm{mL}$ in $30 \%$ hydroxypropyl- $\beta$-cyclodextrin). 
can be applied to preliminary pharmacokinetic studies in animal model leading to an important overview of the drug distribution and elimination process. Kinetica $2000^{\mathrm{TM}}$ software was used and $V d$ and $\mathrm{Kel}$ parameters were calculated. The values found after i.v. dosing $(100 \mathrm{mg} / \mathrm{kg})$ were $0.5 \mathrm{~L}$ and $0.11 \mathrm{~min}$, respectively, meaning a large distribution and rapid elimination rate, as expected for highly lipophilic drugs, as for 4-NRC.

\section{ACKOWLEDGEMENTS}

The authors thank FAPESP grant (PhD degree fellowship at the Programa de Pós-Graduação em Fármaco e Medicamentos, Faculdade de Ciências Farmacêuticas da Universidade de São Paulo) and CAPES for fellowship support. We also thank Dr. Massuo J. Kato and Dr. Mario J. Politi for providing plant material and some laboratory facilities at Universidade de São Paulo.

\section{RESUMO}

\section{Quantificação de 4-nerolidilcatecol de Pothomorphe umbellata (Piperaceae) em amostras de plasma de rato por CLAE-UV}

O 4-nerolidilcatecol representa o metabólito secundário mais abundante de Pothomorphe umbellata (Piperaceae), cujo uso terapêtico deve ser fundamentado após a caracterização farmacocinética do mesmo (4-nerolidicatecol). Os niveis séricos de animais tratados com $10 \mathrm{mg} / \mathrm{kg}$ do fármaco i.v. foram avaliados por validação analítica em CLAE-UV. As condições cromatográficas empregadas foram fase móvel de acetonitrila:metanol:água (62:20:18), coluna RP-18, fluxo de 1,6 mL/min e detector UV em $282 \mathrm{~nm}$, com tempo total de corrida inferior a 15 minutos. Observou-se linearidade do 4-NRC em plasmas na faixa de 1,0 a 80,0 $\mathrm{mcg} / \mathrm{mL}$, com valores de precisão e exatidão entre 14,4$3,0 \%$ e $24,0-0,2 \%$, respectivamente. O procedimento de extração líquido-líquido apresentou reprodutivel e com recuperação quantitativa $(106,5 \% \pm 3,0 \%)$.

UNITERMOS: 4-Nerolidilcatecol. Pothomorphe umbellata. CLAE-UV. Extração líquido-líquido.

\section{REFERENCES}

AMORIM, C. Z.; FLORES, C. A.; GOMES, B. E.; MARQUES, A. D.; CORDEIRO, R. S. B. Screening for antimalarial activity in the genus Pothomorphe. $J$. Ethnopharmacol., v. 24, p. 101-116, 1988.
BARROS, S. M.; TEIXEIRA, D. S.; AZNAR, A. E.; MOREIRA JR., J. A.; ISHII, I.; FREITAS, P. C. D. Antioxidant activity of ethanolic extracts of Pothomorphe umbellata (L.) Miq (pariparoba). Ciênc. Cult., v. 48, p. 114-117, 1996.

BARROS, S.; SAWADA, T. C. H.; ROPKE, C. D.; SILVA, V.V.; PEREIRA, S.M.M.; BARROS, S.B.M. Avaliação mutagênica do extrato hidroalcóolico de Pothomorphe umbellata L. Miq. Rev. Bras. Toxicol., v. 14, n. 2, supl., 2001.p. 96.

BASTOS, W.L. Metabolismo secundário de Pothomorphe umbellata. Araraquara, 1998. 95p. [Dissertação de Mestrado. Instituto de Química, Universidade Estadual Paulista]

BERNARD, H. O.; TIELI, K. Isolierrung von 1-Allyl-2,3dimethoxy-4,5-methylendioxybenzol(=Dill-Apiol) aus Heckeria umbellata (L.) Kunth (Piperaceae). Helv. Chim. Acta, v. 61, p. 215-216, 1978.

BOULTON, D. W.; WALLE, U.K.; WALLE, T. Fate of the flavonoid quercetin in human cell lines: chemical instability and metabolism. J. Pharm. Pharmacol., v. 51, p. 353$359,1999$.

CAI, X.; WOO, M. H.; EDICK, M. J.; RELLING, M. V. Simultaneous quantification of etoposide and its catechol metabolite in human plasma using high-performance liquid chromatography with electrochemical detection. J. Chromatogr. B, v. 728, p. 241-250. 1999.

CASTAGNETTA, L.A.; GRANATA, O.M.; ARCURI, F.P.; POLITO, L.M.; ROSATI, F.; CARTONI, G.P. Gas chromatography/mass spectrometry of catechol estrogens. Steroids, v. 57, p. 437-443, 1992.

DE SMET, P. A. G. M.; ROUWERS, J. R. B. J. Pharmacokinetic evaluation of herbal remedies. Basic introduction, applicability, current status and regulatory needs. Clin. Pharmacokin., v. 32, p. 427-436, 1997.

DERENDORF, H.; EL-DIN, A.; EL-KOUSSI, A.; GARRET, E. R. Electrochemical chromatographic determinations of morphine antagonists in biological fluids, with applications J. Pharm. Sci., v. 73, p. 621-624, 1984. 
DERENDORF, H.; GARRET, E. High performance liquid chromatography assay of methadone, phencyclidine and metabolites by postcolumn ion-pair extraction and online fluorescent detection of the counterion with applications. J. Pharm. Sci., v. 72, p. 630, 1983.

DESMARCHELIER, C.; BARROS, S.B.M.; REPETTO, M; LATORRE, L.R.; KATO, M. J.; CICCIA, G. 4nerolidylcatechol from Pothomorphe spp. scavenges peroxyl radicals and inhibits Fe (II)-dependent DNA damage. Planta Med., v. 63, p. 561-563, 1997.

DI STASI, L. C.; HIRUMA,C. A.; GUIMARÃES, E. M.; SANTOS, C. M. Medicinal plants popularly used in Brazilian Amazon. Fitoterapia, v. 65, p. 529-540, 1994.

EL-SHAFAE, A.M.; EL-DOMIATY, M.M. Improved LC methods for the determination of diosmin and/or hesperidin in plant extracts and pharmaceutical formulations. J. Pharm. Biomed. Anal., v. 26, p. 539-545, 2001.

FELZENSZWALB, I.; VALSA, J.O.; ARAUJO, A. C.; GOMES-ALCANTARA, R. Absence of mutagenicity of Pothomorphe umbellata and Pothomorphe peltata in the Salmonella/mammalian-microsome mutagenicity assay. Braz. J. Med. Biol. Res. v. 20, p. 403-405, 1987.

FREITAS, P.C.D. Atividade antioxidante de espécies medicinais da família Piperaceae Pothomorphe umbellata (L.) Miq e Piper regnelli (Miq.) C. DC. São Paulo, 1999. 115p.[Tese de doutortado. Faculdade de Ciências Farmacêuticas. Universidade de São Paulo].

GARRETT, E.R.; HUNT, C.A. Physicochemical properties, solubility and protein binding of delta-9- THC.J. Pharm. Sci., v. 63, p. 1056-1064, 1974.

GUSTAFSON, K. R.; CARDELLINA II (?), J. H.; MCHAHON, J. B.; PANNELL, L. K.; CRAGG, G. M.; BOYD, M. R. HIV inhibitory natural products. 6 . The peltatols, novel HIV-inhibitory catechol derivatives from Pothomorphe peltata. J. Org. Chem., v. 57, p. 2809-2811, 1992.

HAMBURGUER, M.; HOSTETTMANN, K. Bioactivity in plants: the link between phytochemistry and medicine. Phytochemistry, v. 30, p. 3864-3874, 1991.
HOLMES, C.; EISENHOFER, G.; GOLDSTEIN, D.S. Improved assay for plasma dihydroxyphenylacetic acid and other catechols using high-performance liquid chromatography with electrochemical detection. $J$. Chromatogr. B, v. 653, p. 131-138, 1994.

KIJOA, A.; GIESBRECHT, A.M.; AKISUE, M.K.; GOTTLIEB, O.R.; GOTTLIEB, H.E. The chemistry of Brazilian Piperaceae. 2. 4-nerolidylcatechol from Pothomorphe umbellata. Planta Med., v. 39, p. 85-87, 1980.

LEE, B.L.; ONG, H.Y.; SHI, C.Y.; ONG, C.N. Simultaneous determination of hydroquinone, catechol and phenol in urine using high-performance liquid chromatography with fluorimetric detection. J. Chromatogr., v. 619, p. 259-66, 1993.

LUNTE, S.M. Structural classification of flavonoids in beverages by liquid chromatography with ultravioletvisible and electrochemical detection. J. Chromatogr., v. 384, p. 371-382, 1987.

ROMANOVA, D.; GRANCAI, D.; JOZOVA, B.; BOZEK, P.; VACHALKOVA, A. Determination of apigenin in rat plasma by high-performance liquid chromatography. $J$. Chromatogr. A, v. 870, p. 463-467, 2000.

RÖPKE, C. D.; KANEKO, T. M.; RODRIGUES, R. M.; SILVA, V.; SAWADA, T. C. H.; KATO, M.J.; BARROS, S. B. M. Evaluation of percutaneous absorption of 4nerolidylcathecol from four topical formulations. Int. J. Pharm., v. 249, n.1-2, 109-16, 2002.

ROUSEFF, R.L.; DETTWEILER, G.R.; SWAINE, R.M.; NAIM, M.; ZEHAVI, U. Solid-phase extraction and HPLC determination of 4-vinyl guaiacol and its precursor, ferulic acid, in orange juice. J. Chromatogr. Sci., v. 30, p. $383-387,1992$.

RUPEREZ, F.J.; BARBAS, C.; CASTRO, M.; HERRERA, E. Determination of alpha-tocopherol and alphatocopherol acetate in diets of experimental animals. Study of stability in the diets. J. Chromatogr. A, v. 839, p. 93-99, 1999. 
SHAH, V.P.; MIDHA, K.K.; DIGHE, S.; MCGILVERAY, I.J.; SKELLY, J.P.; YACOBI, A.; LAYLOFF, T.; VISWANATHAN, C.T.; COOK, C.E.; MCDOWALL, R.D.; et al. Analytical methods validation: bioavailability, bioequivalence and pharmacokinetic studies. Conference report. Eur. J. Drug Metab. Pharmacokinet., v. 16, n. 4, p. 249-255, 1991.

SILVA, R. A. D. Pharmacopeia dos Estados Unidos do Brasil. São Paulo: Cia Ed. Nacional, 1926. 649 p.

SILVA, R. A. D. Farmacopéia dos Estados Unidos do Brasil. 2.ed. São Paulo: Siqueira, 1959. 1265 p.

SILVA, G.A.A.B.; BAVER, L. Contribuição ao estudo do óleo essencial de Heckeria umbellata (L.) Kunth. Rev. Bras. Farm., v. 53, p. 9-61, 1972.
STECHER, G.; HUCK, C.W.; POPP, M.; BONN, G.K. Determination of flavonoids and stilbenes in red wine and related biological products by HPLC and HPLC-ESIMS-MS. Fresenius J. Anal. Chem., v. 371, p. 73-80, 2001.

STREMETZNE, S.; JAEHDE, U.; SCHUMACK, W. Determination of the cytotoxic catechol metaboolite of etoposide (3'O-demethyletoposide) in human plasma by high- performance liquid chromatography. $J$. Chromatogr. B, v. 703, p. 209-215, 1997.

Recebido para publicação em 10 de março de 2004. Aceito para publicação em 13 de setembro de 2004. 